\title{
Influence of the Palatine Tonsil Grade on the Morphology of the Maxillary and Mandibular Dental Arches
}

\author{
Influencia del Grado de las Tonsilas Palatinas en la Morfología \\ de los Arcos Dentales Maxilar y Mandibular
}

Inés Pérez ${ }^{1}$; Nilton Alves ${ }^{2,3}$; Claudia Lizana ${ }^{4}$ \& Naira Figueiredo Deana ${ }^{5,6}$

\begin{abstract}
PÉREZ, I.; ALVES, N.; LIZANA, C. \& DEANA, N. F. Influence of the palatine tonsil grade on the morphology of the maxillary and mandibular dental arches. Int. J. Morphol., 38(5):1201-1207, 2020.

SUMMARY: Enlarged palatine tonsils and adenoids are thought to cause obstruction of the upper airway, triggering changes in breathing patterns, which in turn lead to dentofacial alterations, including malocclusions. The object of the present study was to correlate the size (grade) of the palatine tonsil with measurements of the maxillary and mandibular dental arches in children. This was an observational cross-sectional study carried out in 35 children aged between 6 and 11 years. The inter- and intra-arch parameters were measured (horizontal, vertical and sagittal analyses) by making plastercasts and then taking measurements with callipers. The tonsil size was classified in 5 grades from 0-4, using the Brodsky tonsil grading scale. The researcher was calibrated prior to carrying out the measurements. Pearson's chi-squared test was used and Pearson's correlation coefficient was calculated. The SPSS v.22.0 software was used, with a significance threshold of $5 \%$. Six patients were classified as grade 1 , sixteen grade 2, eleven grade 3 , two grade 4 and none of the patients presented grade 0 .A low positive association was found between tonsil grade and the total length of the mandibular arch, a very low positive association between tonsil grade and maxillary inter-first premolar distance, total length of the maxillary arch and depth of the palatine recess. A very low negative association was found for tonsil grade and overjet, overbite, mandibular inter-permanent first molar distance, mandibular inter-first premolar distance, and mandibular and maxillary intercanine widths. No statistically significant correlation was observed for any of the measurements. No association was found between the tonsil grade and Angle's Classification, canine relationship, overjet and overbite. According to the results of this study there is no significant correlation between the dental arches and the tonsil grade.
\end{abstract}

KEY WORDS: Palatine tonsils; Morphology; Dental arches; Children.

\section{INTRODUCTION}

The palatine tonsils are located in the palatoglossal and palatopharyngeal arch in the oropharynx (Alves \& Cândido, 2016). They are more prominent during infancy and are directly proportional to the bacterial load and the number of B and T cells (Siegel et al., 1982). Enlargement of the tonsils and enlargement of the adenoids contribute to the appearance of paediatric illnesses (Webb et al., 2004) and are considered to be among the most common factors contributing to airway obstruction in children (Greenfeld $e t$ al., 2003; Zhu et al., 2016). They therefore generate changes which trigger adaptations and compensations in breathing patterns (Zhu et al.). Normal nasal respiration influences the development of the craniofacial structures, favouring harmonic growth which permits proper interaction with the other components of the head and neck region (Harari et al., 2010). A deterioration in nasal respiration provokes an imbalance in the muscular function of children who breathe through their mouths (Rubin, 1980; McNamara, 1981); as a result, modifications are observed in the growth and development of the dental arches, altering the inter- and intraarch relationships and provoking different types of malocclusions (Diouf et al., 2015).

There are at least three reproducible techniques for clinical measurement of tonsil size described in the literature, namely Brodsky's scale (Brodsky, 1989), the scale of Friedman et al. (1999) and that of Mallampati et al. (1985). Most studies use Brodsky's grading scale, since this method

\footnotetext{
${ }^{1}$ Programa de Magister en Odontología, Facultad de Odontología, Universidad de La Frontera, Temuco, Chile.

${ }^{2}$ Centro de Excelencia en Estudios Morfológicos y Quirúrgicos (CEMyQ), Universidad de La Frontera, Temuco, Chile.

${ }^{3}$ Centro de Investigación en Morfología Aplicada (CIMA), Facultad de Odontología, Universidad de La Frontera, Temuco, Chile.

${ }^{4}$ Programa de Especialidad en Ortodoncia y Ortopedia Bucomaxilofacial, Universidad Católica de Uruguay, Uruguay.

${ }^{5}$ Centro de Investigación en Epidemiología, Economía y Salud Pública Oral (CIEESPO), Facultad de Odontología, Universidad de La Frontera, Temuco, Chile.

${ }^{6}$ Departamento de Odontopediatría e Ortodoncia, Facultad de Odontología, Universidad de La Frontera, Temuco, Chile.
} 
presents greater reproducibility in children than other scales, such as Friedman et al. and Mallampati et al., as well as offering greater inter- and intra-observer reproducibility (Kumar et al., 2014). Early evaluation of the size of the palatine tonsils is important, as it will help the prevention of orthodontic abnormalities caused by obstruction of the upper airway (Diouf et al.) by early intervention. The object of this study was to analyse the influence of the size of the palatine tonsils in the morphology of the maxillary and mandibular dental arches in a population of Chilean children.

\section{MATERIAL AND METHOD}

This was an observational, cross-sectional study. The participants were children resident in the Fifth Region of Chile who attended the Interceptive Orthodontics and Odontopaediatry Polyclinic of the Dental Faculty of Andrés Bello University, Viña del Mar Campus, in 2017 and 2018. Patients who participated in this study were recruited by signature of an informed consent by the parents and/or guardians of the candidates. The children also gave their informed consent after they had been told that they could agree or refuse to take part in the study freely. The patients' data were treated confidentially. The present study was carried out in accordance with the rules of the Helsinki Declaration and was approved by the Scientific Ethics Committee of Universidad de La Frontera, Folio number 021-17.

The participants were aged between 6 and 12 years, and attended the Interceptive Orthodontics and Odontopaediatry Polyclinic of the Dental Faculty of Andrés Bello University, Viña del Mar Campus, between 2017 and 2018. Patients with the following conditions were excluded: (1) history of tonsilectomy, (2) previous or ongoing orthodontic treatment, (3) non-nutritive sucking habit, (4) chronic allergic rhinitis, (5) deviation of the nasal septum (diagnosed from the patient's panoramic digital radiography taken on admission), (6) clinical history of nasal polyps, (7) hypertrophy of lingual tonsils and (8) obstructive adenoids. Hypertrophy of lingual tonsils and obstructive adenoids were evaluated from the patient's teleradiography taken on admission. Diagnosis was by the
X-ray method of Cohen \& Konak (1985), which compares the thickness of the soft palate and the space of the underlying pharyngeal airway, since these factors may influence the size of the arches.

Two initial photographs were taken of each participant with the child sitting at the height of the operator's elbows, mouth open and tongue out; in the first the child was silent and in the second he/she was saying "aah". The photographs were taken with a Nikon D53 digital reflex camera, with circular flash to stabilise the image. The image followed the parameters of MontgomeryDowns et al. (2011), forming an angle of $90^{\circ}$ to the facial midline, at a distance of $20 \mathrm{~cm}$ from the lens to the patient's face. The point of focus was on the palatoglossal pillars. The photographs were not altered, except that the upper and lower lips were cut to reduce the facial features. The following settings were used for all the photographs: diaphragm aperture f22 to $\mathrm{f} 32$, shutter speed $1 / 60$ to $1 / 100$ s and automatic white balance. The photographs were backed up in JPEG format and edited in Adobe Photoshop CC 2015.1. The images were analysed in a non-reflective screen. The working area of the image could be amplified and adjusted (brilliance/contrast/sharpness) if necessary.

The size of the palatine tonsils was determined by Brodsky's tonsil grading scale (1989). This scale is based on the space occupied by the palatine tonsils in the space between the palatoglossal pillars (Table I). The palatine tonsils of all the participants were classified by size grade from the two clinical photographs obtained, by the same observer.

Measurement of the size of palatine tonsils. The patients selected for the study were divided into sub-groups by the size of their palatine tonsils. The different sizes were grouped according to the 5 grades determined by Brodsky's grading scale, based on the space occupied by the palatine tonsils between the palatoglossal pillars (Fig. 1).

Evaluation of maxillary and mandibular dental arches. Study models were prepared using alginate and moulded in extra-hard plaster in order to take measurements of the maxillary and mandibular dental arches, following Diouf et al. (Table II). The measurements were taken from the

Table I. Classification of the size of the palatine tonsils according to Brodsky's tonsil grading scale (1989).

\begin{tabular}{cl}
\hline Grade & Definition \\
\hline 0 & Palatine tonsils limited to the tonsillar fossa \\
1 & Palatine tonsils occupy up to $25 \%$ of the space between the palatoglossal pillars \\
2 & Palatine tonsils occupy between $26 \%$ and $50 \%$ of the space between the pala toglossal pillars \\
3 & Palatine tonsils occupy between $51 \%$ and $75 \%$ of the space between the pala toglossal pillars \\
4 & Palatine tonsils occupy more than $75 \%$ of the space between the palatoglossal pillars. \\
\hline
\end{tabular}




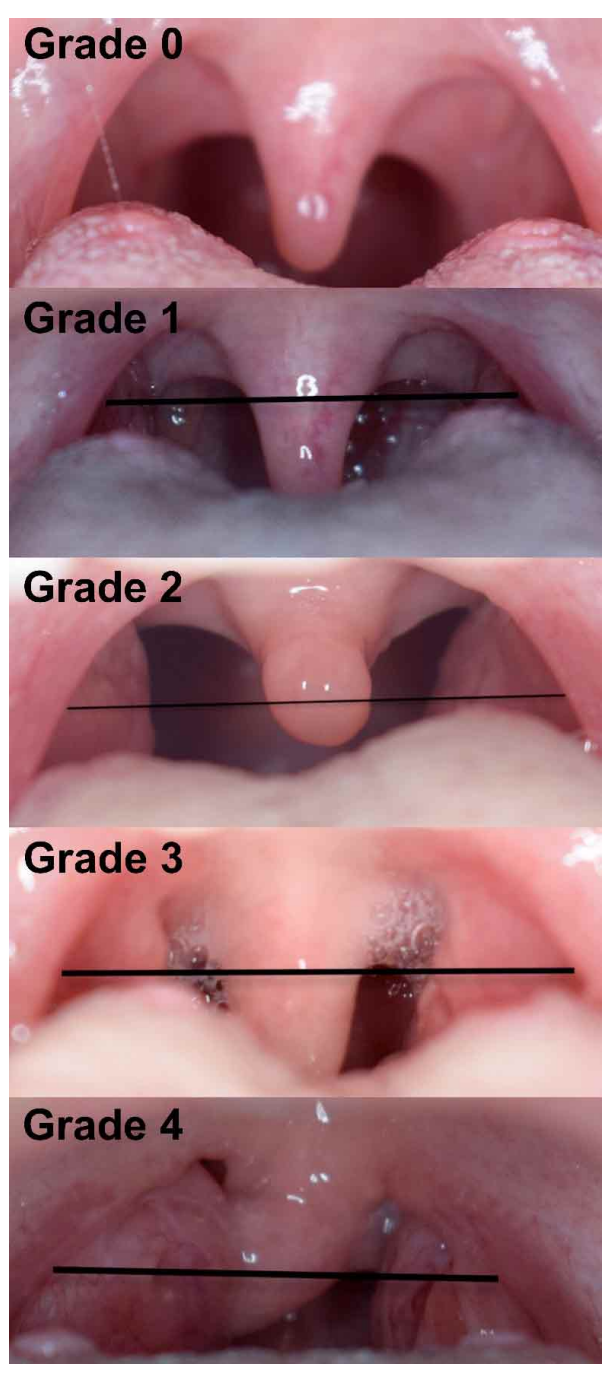

study models by two observers (previously calibrated by an expert orthodontist, who was director of the interceptive orthodontics polyclinic where the investigation was carried out). To test intra-observer reproducibility, a random sample of a certain number of study models was selected for re-evaluation after an interval of 3 weeks, to determine the concordance correlation coefficient.

Statistical analysis. Levene's test was carried out to analyse the homogeneity of variances, and the Shapiro-Wilk test to analyse the normality of the data. One-way ANOVA was carried out, with Tucker's post test to compare the quantitative variables as related to the tonsil grade. Pearson's chi-squared test was carried out to analyse the association between the tonsil grade and the quantitative variables, and the force of association between the variables was evaluated by the phi coefficient (f). The strength of association was interpreted as suggested by Cohen (1988), being classified as small $(0.10)$, medium $(0.30)$, large $(0.50)$ or very large $(\geq 0.70)$. Pearson's correlation was applied to analyse the association between the tonsil grades and the quantitative variables. The association was classified as nil $(\mathrm{r}=0)$, very low $(0<\mathrm{r}<0.20)$, low $(0.20<\mathrm{r}<0.40)$, moderate $(0.40<\mathrm{r}<0.60)$, high $(0.60<\mathrm{r}<0.80)$ and very high $(>0.80)$. The SPSS v.22.0 software was used, with a significance threshold of $5 \%$. The power of the study was analysed post hoc using ANOVA in the G*Power 3.1 software.

Fig. 1. Clinical grading of the size of the palatine tonsils. Grade 0: tonsils limited to the tonsillar fossa; grade 1, tonsils occupying up to $25 \%$ of the space between the anterior pillars of the oropharynx; grade 2, palatine tonsils occupying between the 26 $\%$ and $50 \%$ of the space between the anterior pillars of the oropharynx; grade 3 , palatine tonsils occupying between $51 \%$ and $75 \%$ of the space between the anterior pillars of the oropharynx; grade 4, palatine tonsils occupying more than $75 \%$ of the space between the anterior pillars of the oropharynx.

Table II. Inter-arch and intra-arch parameters analysed.

\begin{tabular}{|c|c|c|}
\hline Analysis & Relation & Parameters \\
\hline \multirow{4}{*}{$\begin{array}{l}\text { Horizontal } \\
\text { analysis }\end{array}$} & & $\begin{array}{l}\text { Maxillary and mandibular intercanine width (distance between the vertices of the canine } \\
\text { cusps) }\end{array}$ \\
\hline & Intra-arch & $\begin{array}{l}\text { Maxillary and mandibular inter-first permanent molar distance (mesio-vestibular cusps of the } \\
1 \text { st permanent molar) }\end{array}$ \\
\hline & & $\begin{array}{l}\text { Inter-first premolar or first deciduous molar distance (distance between vertices of vestibular } \\
\text { cusps of the first premolars or distance between MV cusps of the first decidual molar). }\end{array}$ \\
\hline & Inter-arch & \\
\hline \multirow{2}{*}{ Vertical analysis } & Intra-arch & $\begin{array}{l}\text { Total depth of palatine recess (distance between a line joining the points of the mesio- } \\
\text { vestibular cusps of the maxillary first permanent molars and a point along the palatine raphe). }\end{array}$ \\
\hline & Inter-arch & $\begin{array}{l}\text { Overbite (distance between the free incisal edge of the maxillary central incisor and the free } \\
\text { incisal edge of the mandibular central incisor) }\end{array}$ \\
\hline \multirow[t]{2}{*}{ Sagittal analysis } & Intra-arch & $\begin{array}{l}\text { Total length of the maxillary and mandibular dental arches (distance between the tangent of } \\
\text { the vestibular surface of the central incisors and the tangent of the distal surface of the second } \\
\text { premolars or the distal surface of the second deciduous molars. }\end{array}$ \\
\hline & Inter-arch & Angle's Classification, canine relationship and overjet. \\
\hline
\end{tabular}




\section{RESULTS}

The participants were 35 patients, 15 female and 20 male, aged between 6 and 11 years, mean 8.17 years $( \pm 1.50$ years). The power of the study was analysed by ANOVA post-hoc, with alpha error of 0.05 , size of effect of 0.676 ,

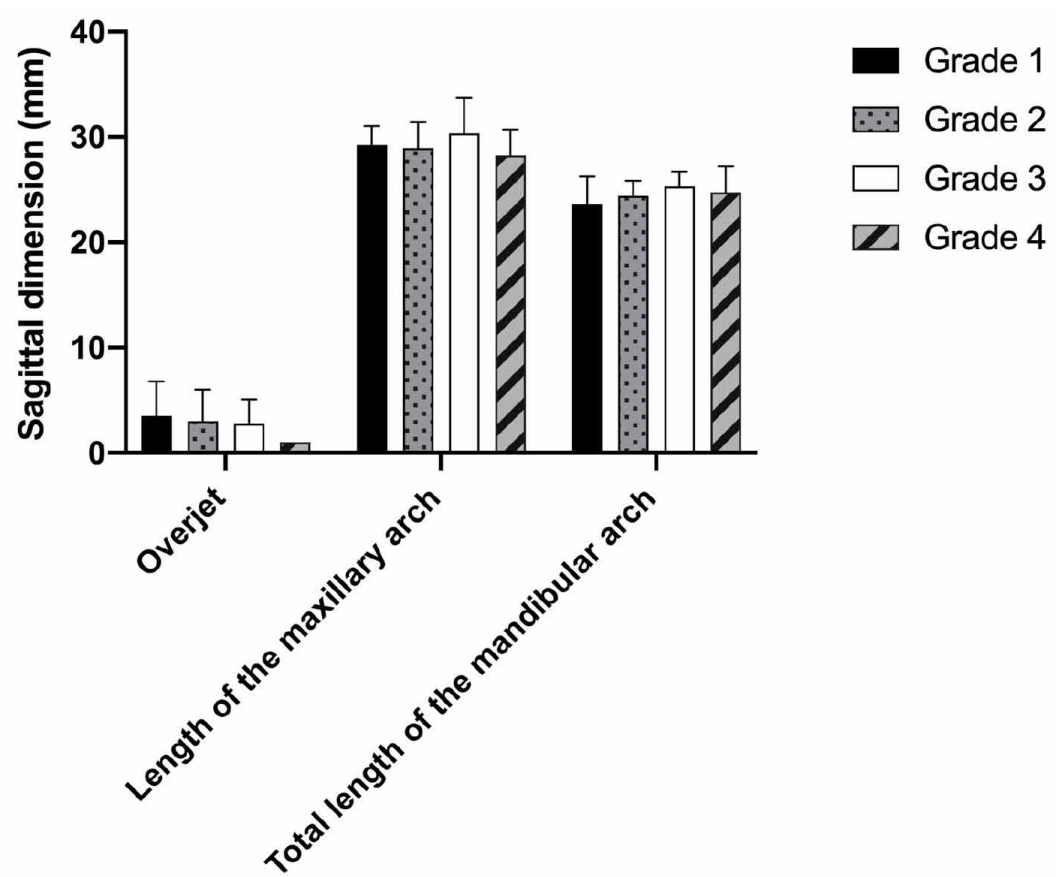

Fig. 2. Distribution of the variables analysed for the sagittal dimension (mean and SD) by tonsil grade.

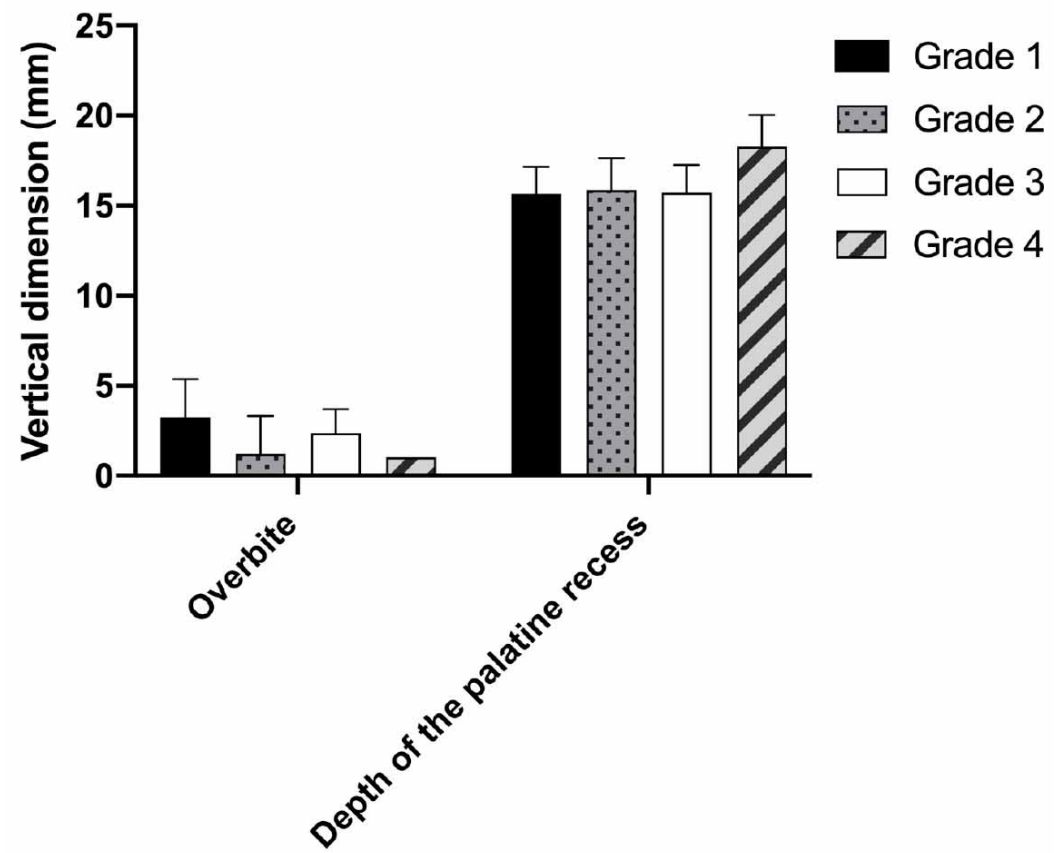

Fig. 3. Distribution of the variables analysed for the vertical dimension (mean and SD) by tonsil grade. obtaining a power of $0.8982(89.82 \%)$; we therefore considered that the number of participants included in the study was sufficient.

The patients were classified into 5 groups by tonsil grade: six patients presented grade 1 , sixteen grade 2 , eleven grade 3 , two grade 4 and none of the patients included in the sample presented grade 0 . The mean values found for the quantitative variables and the percentages found for the qualitative variables are shown in Figures 2 to 4. Oneway ANOVA showed that there were no statistically significant differences between the tonsil grades for the parameters analysed.

The intra-class correlation test showed a high concordance index of 0.999 . No association was observed between the tonsil grade and the qualitative parameters of the dental arch, with p-values higher than 0.05 . The force of association evaluated by the phi coefficient (f) is expressed in Table III. A large force of association was found for Angle's Classification (left side) and the canine relationship (right side); a moderate force was found for the canine relationship (left side) and Angle's Classification (right side); and a medium association for overbite, stable occlusion and overjet. None of the correlations was significant $(\mathrm{p}>0.05)$ (Table III).

Analysis of Pearson's correlation for the quantitative variables is shown in Table IV. A low positive association was found between tonsil grade and the total length of the mandibular arch, a very low positive association between tonsil grade and maxillary inter-first premolar or inter-first deciduous molar distance, maxillary interfirst permanent molar distance, total length of the maxillary arch and depth of the palatine recess. A very low negative association was found for tonsil grade and overjet, overbite, mandibular interpermanent first molar distance, mandibular inter-first premolar or inter-first deciduous molar distance, and mandibular and maxillary intercanine widths. 


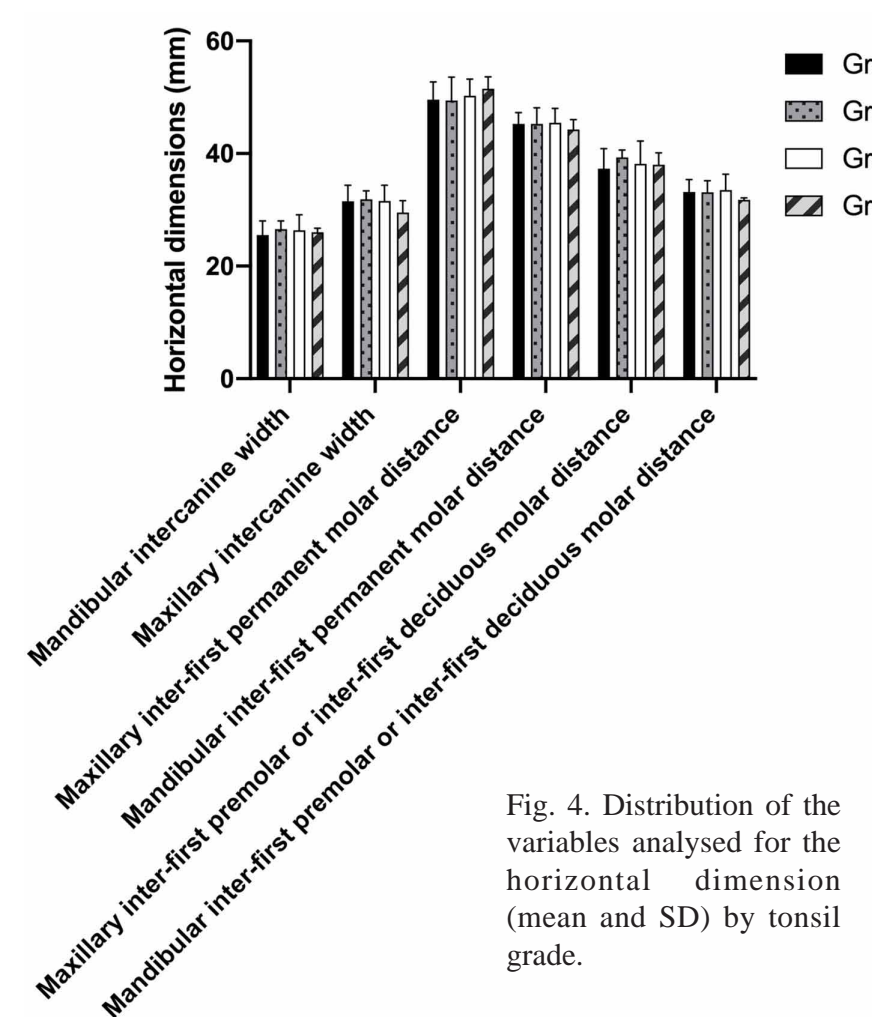

No statistically significant correlation was observed for any of the measurements. We also observed that there was no correlation between tonsil grade and age ( $\mathrm{rho}=0.107, \mathrm{p}=0.542)$ or between tonsil grade and $\operatorname{sex}(\mathrm{f}=0.297, \mathrm{p}=0.379)$.

\section{DISCUSSION}

Enlargement of the palatine tonsils may determine a type of respiratory obstruction as it may cause obstruction of the oropharyngeal space posterior of the root of the tongue (Hultcrantz et al., 1991). Children with serious airway obstruction have a retrognathic mandible, vertical direction of growth and a tendency to Class II malocclusion (FloresMir et al., 2013). Hultcrantz et al. have indicated that a greater percentage of children with enlarged tonsils suffer malocclusion than children with normal tonsil grade. In a meta analysis study, Zhu et al. reported that children with airway obstruction have a narrower maxillary dental arch than children with no airway obstruction.

Table III. Association between the tonsil grade and qualitative parameters of the dental arch and force of association between the variables (phi).

\begin{tabular}{|c|c|c|c|c|c|c|c|}
\hline \multirow[t]{2}{*}{ Variables } & \multirow{2}{*}{$\begin{array}{c}\text { Grade } 1 \\
\mathrm{n} / \%\end{array}$} & \multirow{2}{*}{$\begin{array}{c}\text { Grade } 2 \\
\mathrm{n} / \%\end{array}$} & \multirow{2}{*}{$\begin{array}{c}\text { Grade } 3 \\
\mathrm{n} / \%\end{array}$} & \multirow{2}{*}{$\begin{array}{c}\text { Grade } 4 \\
\mathrm{n} / \%\end{array}$} & \multirow{2}{*}{$\begin{array}{l}\text { Total } \\
\mathrm{n} / \%\end{array}$} & \multicolumn{2}{|c|}{$X^{2}$} \\
\hline & & & & & & p-value & Phi \\
\hline \multicolumn{8}{|c|}{ Stable occlusion } \\
\hline Yes & $2 / 12.5 \%$ & $9 / 56.3 \%$ & $4 / 25.0 \%$ & $1 / 6.3 \%$ & $16 / 45.7 \%$ & 0.685 & 0.206 \\
\hline No & $4 / 21.1 \%$ & $7 / 36.8 \%$ & $7 / 36.8 \%$ & $1 / 5.3 \%$ & $19 / 54.3 \%$ & & \\
\hline \multicolumn{8}{|c|}{ Normal overbite } \\
\hline Yes & $2 / 15.4 \%$ & $7 / 53.8 \%$ & $4 / 30.8 \%$ & $0 / 0.0 \%$ & $13 / 37.1 \%$ & 0.677 & 0.208 \\
\hline No & $4 / 18.2 \%$ & $9 / 40.9 \%$ & $7 / 31.8 \%$ & $2 / 9.1 \%$ & $22 / 62.9 \%$ & & \\
\hline \multicolumn{8}{|c|}{ Angle's classification, right side } \\
\hline Class I & $2 / 10.5 \%$ & $9 / 47.4 \%$ & $7 / 36.8 \%$ & $1 / 5.3 \%$ & $19 / 54.3 \%$ & 0.607 & 0.359 \\
\hline Class II & $4 / 28.6 \%$ & $5 / 35.7 \%$ & $4 / 28.6 \%$ & $1 / 7.1 \%$ & $14 / 40.0 \%$ & & \\
\hline Class III & $0 / 0.0 \%$ & $2 / 12.5 \%$ & $0 / 0.0 \%$ & $0 / 0.0 \%$ & $2 / 5.7 \%$ & & \\
\hline \multicolumn{8}{|c|}{ Angle's classification, left side } \\
\hline Class I & $2 / 11.1 \%$ & $7 / 38.9 \%$ & $7 / 38.9 \%$ & $2 / 11.1 \%$ & $18 / 51.4 \%$ & 0.182 & 0.503 \\
\hline Class II & $4 / 30.8 \%$ & $5 / 38.5 \%$ & $4 / 30.8 \%$ & $0 / 0.0 \%$ & $13 / 37.1 \%$ & & \\
\hline Class III & $0 / 0.0 \%$ & $4 / 25.0 \%$ & $0 / 0.0 \%$ & $0 / 0.0 \%$ & $4 / 11.4 \%$ & & \\
\hline \multicolumn{8}{|c|}{ Canine relationship, right side } \\
\hline Class I & $1 / 4.5 \%$ & $13 / 59.1 \%$ & $6 / 27.3 \%$ & $2 / 9.1 \%$ & $22 / 62.9 \%$ & 0.059 & 0.589 \\
\hline Class II & $5 / 41.7 \%$ & $2 / 16.7 \%$ & $5 / 41.7 \%$ & $0 / 0.0 \%$ & $12 / 34.3 \%$ & & \\
\hline \multicolumn{8}{|c|}{ Canine relationship, left side } \\
\hline Class I & $3 / 14.3 \%$ & $9 / 42.9 \%$ & $7 / 33.3 \%$ & $2 / 9.5 \%$ & $21 / 60.0 \%$ & 0.441 & 0.408 \\
\hline Class II & $3 / 27.3 \%$ & $4 / 36.4 \%$ & $4 / 36.4 \%$ & $0 / 0.0 \%$ & $11 / 31.4 \%$ & & \\
\hline \multicolumn{8}{|c|}{ Normal overjet } \\
\hline Yes & $5 / 20.8 \%$ & $9 / 37.5 \%$ & $8 / 33.3 \%$ & $2 / 8.3 \%$ & $24 / 68.6 \%$ & 0.434 & 0.280 \\
\hline No & $1 / 9.1 \%$ & $7 / 63.6 \%$ & $3 / 27.3 \%$ & $0 / 0.0 \%$ & $11 / 31.4 \%$ & & \\
\hline
\end{tabular}


Table IV. Pearson's correlation coefficient between the tonsil grade and the quantitative parameters of the dental arch.

\begin{tabular}{lcc}
\hline Variables & \multicolumn{2}{c}{$\begin{array}{c}\text { Grades } 1,2,3,4 \\
\text { p-value }\end{array}$} \\
\hline Sagittal dimension & & \\
Overj et (mm) & -0.169 & 0.332 \\
Total length of the maxillary arch (mm) & 0.091 & 0.604 \\
Total length of the man dibular arch (mm) & 0.294 & 0.086 \\
Vertical dimension & & \\
Overbite (mm) & -0.124 & 0.480 \\
Depth of the palatine recess (mm) & 0.181 & 0.298 \\
Horizontal dimension & & \\
Maxillary inter-first permanent molar distance (mm) & 0.134 & 0.443 \\
Mandibular inter-first permanent molar distance (mm) & -0.026 & 0.882 \\
Maxillary inter-first premolar or inter-first deciduous molar distance (mm) & 0.014 & 0.936 \\
Mandibular inter-first premolar or inter-first deciduous molar distance (mm) & -0.027 & 0.878 \\
Mandibular inter canine width (mm) & -0.149 & 0.781 \\
Maxillary intercanine width (mm) & -0.128 & 0.465 \\
\hline
\end{tabular}

In the present study we analysed the influence of tonsil grade on the morphometry of the dental arches in children aged between 6 and 12 years. We also correlated the tonsil grade with age and sex, finding no significant correlation between any of the variables analysed. In a previous study, Diouf et al. failed to present a significant correlation between the tonsil grade and the quantitative dental variables of the dental arch in the sagittal dimension (overjet, total lengths of the maxillary and mandibular arches); this finding is similar to that of the present study and the study of Valera et al. (2003) who found no correlation between tonsillar enlargement and overjet. In the present study we found no correlation between the depth of the recess and tonsil grade; this does not agree with earlier studies in which a significant positive correlation is reported between these variables (Behlfelt et al., 1989; Diouf et al.). Diouf et al. further reported a significant negative correlation between tonsil grade and maxillary intercanine width, maxillary inter-first premolar width and maxillary inter-first molar width; these findings were not corroborated by the present study. Valera et al. indicated that enlarged palatine tonsils contribute to obstruction of the upper airways, leading to respiratory disorders which may determine narrowing of the maxillary arch; this agrees with the findings of Behlfelt et al., who also related the presence of a narrower maxillary arch with higher tonsil grade.

Furthermore, in our study we found no correlation between qualitative variables and tonsil grade. In contrast to our study, Diouf et al. found a marked association between qualitative variables and tonsil grade, reporting that a normal-sized tonsil was associated with a Class I canine relationship, normal occlusion and normal overbite, while an enlarged tonsil was strongly related with a Class II molar relationship and posterior crossbite with functional lateral deviation of the mandible.

In the present study, no significant correlation was found between age and tonsil grade. Diouf et al. found a significant negative correlation between these variables, however the degree of correlation was small $(\mathrm{rho}=-0.29)$.

Early evaluation of the size of the palatine tonsils would help to prevent orthodontic anomalies caused by obstruction of the upper airway (Diouf et al.), especially if the children are operated before the age of 6 years (Hultcrantz et al.). Other studies, however, say that it is not easy to predict the effect of an adenoidectomy or a tonsilectomy on the morphology of the dental arches (Zhu et al.), showing that the literature presents diverging results concerning the prevention of dental alterations, following tonsil extraction surgery. In any case, for early intervention, it is important for the dentist to carry out rigorous evaluation in children who present respiratory alterations, thereby avoiding possible orthodontic alterations.

In the present study none of the qualitative or quantitative parameters could be associated with tonsil grade in Chilean children. Although a power of $89.82 \%$ was found in this study with a sample of 35 patients, we believe that the sample size should be increased in future research, principally because we had no case of a patient with normal tonsils (grade 0 ) and only 2 patients with grade 4. This may have affected the comparisons in the present study which found no association between the parameters analysed. 
PÉREZ, I.; ALVES, N.; LIZANA, C. \& DEANA, N. F. Influencia del grado de las tonsilas palatinas en la morfología de los arcos dentales maxilar y mandibular. Int. J. Morphol., 38(5):1201-1207, 2020 .

RESUMEN: Se ha considerado que el grado del tamaño de las tonsilas palatinas y los adenoides pueden ser factores que generan obstrucción de la vía aérea superior, desencadenando cambios en el patrón de respiración, lo que provoca alteraciones dentofaciales, entre ellas, maloclusiones. El objetivo del presente estudio fue correlacionar el grado tonsilar palatino con medidas de los arcos dentales maxilar y mandibular en niños. Se realizó un estudio observacional de corte transversal. Fueron incluidos 35 niños entre 6 y 11 años de edad. Fueron medidos parámetros interarco e intra-arco (análisis transversal, vertical, sagital). Para eso fueron tomados modelos de yeso y luego las medidas fueron realizadas con un caliper. El grado tonsilar fue clasificado en 5 grados (0-5), de acuerdo a la escala de graduación de Brodsky. Para la realización de las mediciones el evaluador fue previamente calibrado. Se realizó la prueba Chi-cuadrado de Pearson, y coeficiente de correlación de Pearson. Se utilizó el software SPSS 22.0, considerándose umbral de significación de $5 \%$. Seis pacientes fueron clasificados en grado 1 , dieciséis grado 2 , once grado 3 , dos grado 4 y ningún paciente presentó grado 0 . Se encontró una asociación positiva baja entre grado tonsilar y la longitud total del arco mandibular, positiva muy baja entre grado tonsilar y distancia inter-primer premolar maxilar, longitud total del arco maxilar y profundidad de la bóveda palatina. Una asociación negativa muy baja fue encontrada para el grado tonsilar y overjet, overbite, distancia inter-primer molar permanente mandibular, distancia interprimer premolar mandibular, ancho intercanino mandibular y maxilar. Se observó ausencia de correlación estadísticamente significativa para todas las medidas. No se encontró asociación entre el grado tonsilar y clase molar de Angle, relación canina, overjet y overbite. Según los resultados de este estudio no se aprecia una correlación significativa entre los arcos dentales y el grado tonsilar.

PALABRAS-CLAVE: Tonsilas palatinas; Morfología; Arcos dentales; Niños.

\section{REFERENCES}

Alves, N. \& Cândido, P. Anatomia para o Curso de Odontologia Geral e Específica. $4^{\text {th }}$ ed. São Paulo, Gen-Santos, 2016.

Behlfelt, K.; Linder-Asronson, S.; McWilliam, J.; Neander, P. \& LaageHellman, J. Dentition in children with enlarged tonsils compared to control children. Eur. J. Orthod., 11(4):416-29, 1989.

Brodsky, L. Modern assessment of tonsils and adenoids. Pediatr. Clin. North Am., 36(6):1551-69, 1989.

Cohen, D. \& Konak, S. The evaluation of radiographs of the nasopharynx. Clin. Otolaryngol. Allied Sci. 10(2):73-8, 1985.

Cohen, J. Statistical Power Analysis for the Behavioral Sciences. $2^{\text {nd }}$ ed. Hillsdale (N.J.), Lawrence Erlbaum and Associates, 1988.

Diouf, J. S.; Ngom, P. I.; Sonko, O.; Diop-Bâ, K.; Badiane, A. \& Diagne, F. Influence of tonsillar grade on the dental arch measurements. Am. J. Orthod. Dentofacial Orthop., 147(2):214-20, 2015.

Flores-Mir, C.; Korayem, M.; Heo, G.; Witmans, M.; Major, M. P. \& Major, P. W. Craniofacial morphological characteristics in children with obstructive sleep apnea syndrome: a systematic review and meta-analysis. J. Am. Dent. Assoc., 144(3):269-77, 2013.

Friedman, M.; Tanyeri, H.; La Rosa, M.; Landsberg, R.; Vaidyanathan, K.; Pieri, S. \& Caldarelli, D. Clinical predictors of obstructive sleep apnea. Laryngoscope, 109(12):1901-7, 1999.

Greenfeld, M.; Tauman, R.; DeRowe, A. \& Sivan, Y. Obstructive sleep apnea syndrome due to adenotonsillar hypertrophy in infants. Int. J. Pediatr. Otorhinolaryngol., 67(10):1055-60, 2003.

Harari, D.; Redlich, M.; Miri, S.; Hamud, T. \& Gross, M. The effect of mouth breathing versus nasal breathing on dentofacial and craniofacial development in orthodontic patients. Laryngoscope, 120(10):2089-93, 2010.

Hultcrantz, E.; Larson, M.; Hellquist, R.; Ahlquist-Rastad, J.; Svanholm, H. \& Jakobsson, O. P. The influence of tonsillar obstruction and tonsillectomy on facial growth and dental arch morphology. Int. J. Pediatr. Otorhinolaryngol., 22(2):125-34, 1991.

Kumar, D. S.; Valenzuela, D.; Kozak, F. K.; Ludemann, J. P.; Moxham, J. P.; Lea, J. \& Chadha, N. K. The reliability of clinical tonsil size grading in children. JAMA Otolaryngol. Head Neck Surg., 140(11):1034-7, 2014.

Mallampati, S. R.; Gatt, S. P.; Gugino, L. D.; Desai, S. P.; Waraksa, B.; Freiberger, D. \& Liu, P. L. A clinical sign to predict difficult tracheal intubation: a prospective study. Can. J. Anaesth. Soc. J., 32(4):429-34, 1985.

McNamara, J. A. Influence of respiratory pattern on craniofacial growth. Angle Orthod., 51(4):269-300, 1981.

Rubin, R. M. Mode of respiration and facial growth. Am. J. Orthod., 78(5):504-10, 1980.

Siegel, G.; Linse, R. \& Macheleidt, S. Factors of tonsillar involution: agedependent changes in B-cell activation and Langerhans' cell density. Arch. Otorhinolaryngol., 236(3):261-9, 1982.

Valera, F. C.; Travitzki, L. V.; Mattar, S. E.; Matsumoto, M. A.; Elias, A. M. \& Anselmo-Lima, W. T. Muscular, functional and orthodontic changes in pre school children with enlarged adenoids and tonsils. Int. J. Pediatr. Otorhinolaryngol., 67(7):761-70, 2003.

Webb, C. J.; Osman, E.; Ghosh, S. K. \& Hone, S. Tonsillar size is an important indicator of recurrent acute tonsillitis. Clin. Otolaryngol. Allied Sci., 29(4):369-71, 2004.

Zhu, Y.; Li, J.; Tang, Y.; Wang, X.; Xue, X.; Sun, H.; Nie, P.; Qu, X. \& Zhu, M. Dental arch dimensional changes after adenoidectomy or tonsillectomy in children with airway obstruction: A meta-analysis and systematic review under PRISMA guidelines. Medicine (Baltimore), 95(39):e4976, 2016.

\section{Corresponding author: \\ Nilton Alves \\ Universidad de La Frontera \\ Faculty of Dentistry \\ 1145 Francisco Salazar \\ PO BOX 54-D \\ Temuco \\ Postal Code: 4780000 \\ CHILE}

Email: nilton.alves@ufrontera.cl

ORCID ID: 0000-0001-7878-1810

Received: 24-02-2020

Accepted: 23-04-2020 